\author{
PRIMARY: JURNAL PENDIDIKAN GURU SEKOLAH DASAR \\ VOLUME 10 NOMOR 6 DESEMBER 2021 \\ ISSN : 2303-1514 | E-ISSN : 2598-5949 \\ DOI : http://dx.doi.org/10.33578/jpfkip.v10i6.8345 \\ https://primary.ejournal.unri.ac.id/index.php/JPFKIP
}

\title{
PENGEMBANGAN MODUL CERITA BERGAMBAR BERBASIS E-LEARNING MATERI AKTIVITAS EKONOMI PADA MATA PELAJARA IPS
}

\author{
Nopiani $^{1}$, Nana Hendracipta ${ }^{2}$, A. Syachruroji ${ }^{3}$ \\ 1,2,3 Universitas Sultan Ageng Tirtayasa /Serang, Indonesia \\ 'nopiani12345@gmail.com, ${ }^{2}$ nanahendracipta@untirta.ac.id ${ }^{3}$ ahmadsyachruroji@untirta.ac.id.
}

\section{DEVELOPING PICTORIAL STORY MODULES BASED ON E-LEARNING FOR THE MATERIAL OF ECONOMIC ACTIVITIES ON SOCIAL SCIENCE SUBJECTS}

\begin{tabular}{|c|c|}
\hline ARTICLE HISTORY & ABSTRACT \\
\hline $\begin{array}{l}\text { Submitted: } \\
\text { 11 Juni } 2021 \\
11^{\text {th }} \text { June } 2021\end{array}$ & $\begin{array}{l}\text { Abstract: This research aimed to know the development and worthiness of the pictorial story } \\
\text { modules based on e-learning for the materials of economic activities on the social science } \\
\text { subject, and to know learners' responses to the pictorial story modules based on e-learning for } \\
\text { the materials of economic activities on the social science subject. The method used in this study } \\
\text { was the research and development (RND) from Borg \& Gall. This development used only } 6 \\
\text { steps out of } 10 \text { steps, because of the time limit and the cost of researchers. The product } \\
\text { assessment for the module's worthiness test was conducted by three experts: media experts, } \\
\text { linguists, and materials experts, with the test subjects of scale limited to } 20 \text { students at Class } \\
\text { IV-B of SD Negeri } 13 \text {. The results of the feasibility of the module were } 88 \% \text {, meaning that the } \\
\text { percentage value was categorized as "very worthy" criteria. Meanwhile, the results of the } \\
\text { questionnaire of the students' response obtained a percentage of } 94 \% \text {. Thus, it was categorized } \\
\text { as "very worthy" criteria and exceeded the established research success criteria. }\end{array}$ \\
\hline
\end{tabular}

Keywords: IPS, e-learning, picture story module, economic activity

Accepted:

20 Oktober 2021

$20^{\text {th }}$ October 2021

\begin{abstract}
Abstrak: Penelitian ini betujuan untuk mengetahui pengembangan dan kelayakan modul cerita bergambar berbasis e-learning materi aktivitas ekonomi pada mata pelajaran ilmu pengetahuan sosial, serta mengetahui respon peserta didik terhadap modul cerita bergambar berbasis e-learning materi aktivitas ekonomi pada mata pelajaran ilmu pengetahuan sosial. Metode yang diguakan dalam penelitian ini adalah Research and Development (RnD) dari Borg \& Gall. Pengembangan ini hanya menggunakan 6 langkah dari 10 langkah, karena keterbatasan waktu dan biaya peneliti. Penilaian produk untuk uji kelayakan modul dilakukan oleh 3 ahli yaitu ahli media, ahli bahasa dan ahli materi dengan sasaran uji coba produk skala terbatar yaitu siswa kelas IV-B SD Negeri Serang 13 yang berjumlah 20 orang. Hasil dari uji kelayakan penelitian pengembangan modul cerita bergambar berbasis e-learning sebesar $88 \%$, artinya nilai persentase tersebut termasuk kedalam kriteria "sangat layak". Sedangkan untuk hasil angket respon peserta didik yang telah diakumulasikan mendapatkan hasil persentase sebesar 94\% dengan demikian hasil persentase tersebut termasuk kedalam kriteria

"sangat layak" dan melampaui kriteria keberhasilan penelitian yang telah ditetapkan.
\end{abstract}

Published:

27 Desember 2021

$27^{\text {th }}$ December 2021

Kata Kunci : IPS, e-learning, modul cerita bergambar, aktivitas ekonomi

\section{CITATION}

Nopiani, N., Hendracipta, N., \& Syachruroji, A. (2021). Pengembangan Modul Cerita Bergambar Berbasis E-Learning Materi Aktivitas Ekonomi Pada Mata Pelajaran IPS. Primary: Jurnal Pendidikan Guru Sekolah Dasar, 10 (6), 1616-1626. DOI: http://dx.doi.org/10.33578/jpfkip.v10i6.8345

\section{PENDAHULUAN}

Pembelajaran merupakan sebuah proses interaksi antara peserta didik dan pendidik dengan bantuan sumber belajar pada suatu lingkungan belajar. Dalam pembelajaran, proses yang terjadi berisikan bantuan untuk peserta didik yang dilakukan oleh pendidik agar terjadi perolehan ilmu pengetahuan, sikap 
serta keterampilan pada peserta didik. Pemberian bantuan ini pula ditujukan agar peserta didik mampu melaksanakan proses pembelajaran dengan baik dan efisien. Dalam peroses pembelajaran yang dilaksanakan dapat kita ketahui bahwasannya, dalam proses pembelajaran tentu sangat memerlukan sebuah bahan ajar yang tidak bisa dikesampingkan keberadaanya. Karena, pada dasarnya bahan ajar merupakan segala bentuk bahan yang dapat membantu guru dalam melaksankaan proses pembelajaran. Bahan ajar yang digunakan dapat berupa informasi, teks atau alat yang disusun secara runtun dan sistematis yang mencerminkan kompetensi pembelajaran dan tujuan pembelajaran yang akan dicapai oleh peserta didik. Bahan ajar ini dapat berbentuk, buku pelajaran, handout, modul, bahan ajar audio, LKS, bahan ajar interaktif dan lain sebagainya.

Salah satu bahan yang dapat dipilih adalah modul. Seperti yang telah dikemukakan oleh (Prastowo, 2012:106) dimana modul merupakan sebuah bahan ajar yang ditulis secara runtun dengan menggunakan bahasa yang mudah dimengerti oleh peserta didik sesuai dengan tingkat pengetahuan dan umur peserta didik, sehingga peserta didik dapat belajar secara mandiri dengan bimbingan dan bantuan minimal oleh pendidik. Penyesuaian dengan peserta didik ini, ditujukan agar modul memiliki manfaat dalam proses pembelajaran, lebih lengkap dijelaskan oleh Andriani dalam (Prastowo, 2012:109) yang mengemukakan bahwa modul dalam proses pembelajaran memiliki fungsi sebagai penyedia informasi dasar, karena dalam modul menyajikan berbagai informasi dan materi pokok yang masih bisa dikembangkan kembali; dapat menjadi bahan intruksi dan petunjuk bagi peserta didik; serta menjadi bahan pelengkap yang digunakan dalam proses pembelajaran yang dapat dilengkapi dengan ilustrasi atau gambar, foto yang bersifat komunikatif.

Modul cerita bergambar merupakan sebuah bahan ajar yang disusun untuk dapat memberikan sebuah materi pelajaran yang menarik, dilengkapi dengan berbagai kata-kata yang saling berhubungan antara satu dengan yang lainnya sehingga menjadi sebuah satu kesatuan yang saling berkaitan dan tidak berdiri sendiri dengan gambar pendukung yang dikemas sedemikian agar dapat menarik peserta didik dalam membacanya. Selain menambahkan berbagai gambar dalam sebuah modul untuk menggambarkan materi yang disampaikan, cara lain agar bahan ajar modul dapat lebih diminati peserta didik atau pembaca adalah dengan penggunaan modul elektronik. Modul elektronik merupakan tampilan berisi informasi atau naskah dalam format buku, yang disajikan secara elektronik dan dapat dibuka serta dibaca menggunakan komputer atau alat pembaca buku elektronik.

Berdasarkan hasil analisis kebutuhan yang dilakukan di SDN Serang 13 pada tanggal 27 November 2020 diketahui bahwa pembelajaran selama masa covid-19 guru menggunakan pembelajaran daring dan luring untuk mengumpulkan tugas. Pembelajaran daring dilakukan guru dan peserta didik melalui aplikasi WhatsApp dan terkadang menggunakan GoogleForm, dan pengumpulan dilaksanakan pada hari Jumat dengan tetap mengikuti protokol kesehatan yang telah ditentukan. Pembelajaran yang dilaksanakan dengan pemberian materi pelajaran melalui WhatsApp dapat dilakukan dengan cara Voicenote, pemberian link youtube atau foto materi dari bahan ajar tambahan dari guru. Terdapat beberapa kesulitan yang dialami pada saat pembelajaran IPS selama pembelajaran jarak jauh ini diantara yaitu guru tidak bertemu secara langsung sehingga guru tidak bisa mengukur seberapa paham peserta didik terhadap materi yang telah disampaikan, dan guru tidak bisa memastikan apakah peserta didiknya belajar dengan sungguh-sungguh ataupun tidak. Kemudian ditambah guru hanya menggunakan satu bahan ajar yaitu buku tematik untuk siswa.

Berdasarkan masalah yang ditemukan, maka salah satu upaya yang dapat dilakukan untuk mengatasi permasalahan tersebut adalah 
dengan melakukan pengembangan modul cerita bergambar berbasis e-learning untuk meningkatkan semangat dalam belajar. Dengan dilakukannya pengembangan modul cerita bergambar berbasis e-learning ini diharapkan siswa tidak merasa jenuh dan bosan dalam belajar karena peserta didik dapat menggunakannya kapan saja dan dimana saja. Karena itu peneliti melakukan penelitian yang berjudul "Pengembangan Modul Cerita Bergambar Berbasis E-Learning Materi Aktivitas Ekonomi Pada Mata Pelajaran Ilmu Pengetahuan Sosial Kelas IV Sekolah Dasar".

\section{KAJIAN TEORI}

Sebagai mata pelajaran yang diajarkan di satuan pendidikan atau persekolah, serta perpaduan dari beberapa ilmu sosial yang diintegrasikan menjadi sebuah bahan untuk mendidik warga negara Indonesia untuk mampu memahami hak dan kewajiban dalam kehidupan bermasyarakat berbangsa dan bernegara. pendidikan ilmu pengetahuan ini telah resmi dipergunakan sebagai mata pelajaran sejak tahun 1975. Soemantri dalam Jamaludin (2018:1) menjelaskan bahwa ilmu pengetahuan sosial sebagai mata pelajaran yang berjalan dalam bidang sosial, program ilmu pengetahuan sosial memilih serta mengorganisasikan bahan pembelajaran dari berbagai disiplin ilmu yang disajikan secara psikologis untuk tujuan pendidikan. Menurut Hidayati dalam (Ariesta, 2018:26) pendidikan IPS bertujuan agar dapat membina peserta didik agar mampu menjadi warga negara yang baik dan memiliki kepedulian sosial yang berguna untuk dirinya sendiri, masyarakat dan negara.

Setiap mata pelajaran atau ilmu pengetahuan tentunya akan memiliki karakteristik masing-masing yang membedakan antara mata pelajaran yang satu dengan yang lainnya, tidak terkecuali mata pelajaran IPS. (Jamaludin, 2018:13) menyatakan bahwasanya konsep dalam sebuah pembelajaran IPS yaitu sebagai berikut: interaksi, saling ketergantungan, kesinambungan dan perubahan, kesamaan/keragaman/perbedaan, konflik dan konsesus, pola (porton), tempat, kekuasaan, nilai kepercayaan, kelangkaan (scarcity), keadilan dan pemerataan, budaya (culture), nasionalisme, kekhusuan. Materi yang di ajarkan dalam pembelajaran yang berkaitan dengan pembeajaran IPS tentuah banyak slaah satunya yaitu materi aktivtas ekonomi dimana menurut (Sutoyo, 2009:108) Materi ini menjelaskan tentang bentuk aktivitas ekonomi beserta contohnya. Bentuk aktivitas ekonomi dapat dibedakan menjadi tiga kelompok, yaitu aktivitas produksi, aktivitas distribusi dan aktivitas konsumsi. Matei ini disampaikan tentulah untuk memberikan pengetahuan mengenai keistimewaan yang dimiliki bangsa negara Indonesia yang sangat kaya sehingga peserta didik dibentuk dan diberikan pengetahuan untuk mampu meningkatkan dan melestarikan kekayaan yang ada.

Sistem pembelajaran yang dilaksanakan akan selalu berubah untuk menjadi lebih baik, hal ini dipengaruhi oleh beberapa faktor, perkembangan ilmu pengetahuan dan teknologi dapat menjadi salah satu faktor terbentuknya sistem pembelajaran baru, bahkan perkembangan ilmu teknologi dan komuikasi juga dapat bermanfaat bukan hanya dalam pembelajaran namun dapat berguna untuk memudahkan setiap pekerjaan manusia. Dijelaskan oleh Soekartawi dalam (Darmawan, 2016:25) e-learning merupakan salah satu penerapan teknologi informasi yang baru, di Indonesia sendiri, e-learning mulai ada sejak dibukanya IndoInternet sebagai penyedia jasa layanan internet untuk yang pertama. E-learning tersusun dari dua bagian yaitu " $e$ " dan "learning". "e" memiliki kepanjangan 'electronic' dan "learning" memiliki arti 'pembelajaran' sehingga $e$ learning dapat diartikan sebagai suatu pembelajaran yang menggunakan bantuan/jasa perangkat elektronika, yaitu perangkat computer, dengan hal ini e-learning sering disebut juga dengan on-line course. 
Selanjutnya (Harista, 2020:154) juga mengemukakan pendapatnya mengenai $e$ learning, e-learning merupakan suatu metode alternatif dalam pembelajaran untuk memberikan kemudahan pada proses belajar, e-learning merupakan cara yang relative cepat untuk mendistribusikan bahan ajar dan materi, e-learning juga dapat diperbaharui dengan cepat. Siahaan dalam (Darmawan, 2016:29) menjelaskan mengenai fungsi dan manfaat $e$ learning yaitu sebagai suplemen (tambahan), komplemen (pelengkap), substitusi (pengganti). Dari penjelasan mengenai $e$ learning di atas, dapat kita ketahui bahwasannya pembelajaran berbasis e-learning ini adalah suatu proses pembelajaran yang dimana dalam pembelajarannya dilakukan dengan berbantuan alat-alat elektronik agar mampu mengakses materi pembelajaran yang disajikan baik melalui video, e-book, blog, web.

(Prastowo, 2012:106) mengemukakan bahwa modul merupakan sebuah bahan ajar yang ditulis secara runtun dengan menggunakan bahasa yang mudah dipahami oleh peserta didik sesuai dengan tingkat pengetahuan dan umur peserta didik, sehingga peserta didik dapat belajar secara mandiri dengan bimbingan dan bantuan minimal oleh pendidik. Karakteristik dari sebuah modul dijelaskan oleh (Prastowo, 2012:110) yaitu sebagai berikut, dirancang untuk sistem pembelajaran mandiri, program pembelajaran yang urut dan sistematis, memiliki tujuan, memiliki bahan, memiliki kegiatan, terdapat evaluasi, disajikan secara komunikatif cakupan bahasa yang terukur dan terfokus, diupayakan untuk dapat mengganti beberapa peran pendidik, dapat meningkatkan ektivitas pembelajaran. Fungsi modul dalam pembelajaran dijelaskan oleh (Prastowo, 2012:107) yang mengemukakan mengenai fungsi modul dalam pembelajaran.

1. Bahan ajar mandiri, artinya penggunaan modul berfungsi untuk meningkatkan kemampuan peserta didik dalam mencari informasi secara mandiri tanpa bergantung dengan kehadiran pendidik.

2. Pengganti fungsi pendidik,dalam hal ini sebuah modul harus bisa menjelaskan dengan baik kepada peserta didik mengenai materi yang akan disampaikan kepada peserta didik sesuai dengan pengetahuan dan usia peserta didik.

3. Sebagai alat evaluasi. Maksudnya, dengan menggunakan modul peserta didik dapat mengetahui tingkat kemapuan yang dimilikinya terhadap materi yang dielajari.

4. Sebagai bahan rujukan bagi peserta didik.

Dalam sebuah modul cerita bergambar, terdapat dua komponen penyususn modul cerita bergambar tersebut yaitu teks dan gambar. teks dan gambar yang digunakan memiliki keterkaitan dan kesinambungan dalam penyampaian sebuah materi atau pesan yang akan disampaikan pada peserta didik sebagai sasaran awal dibuatnya sebuah modul.

1. Gambar, Mengenai pengertian gambar (Aprilia, 2018:5) mengemukakan pendapatnya bahwa gambar adalah sebuah tiruan terhadap sesuatu seperti barang, tumbuhan, hewan dan lainnya. Pendapat lain dikemukakan oleh (Afnida, 2016:53) yang menyatakan, gambar merupakan sebuah media yang dapat menarik perhatian dan disukai peserta didik, karena di dalam sebuah gambar terdapat bentukbentuk objek dan warna yang jelas sehingga peserta didik akan dengan mudah dalam menggambarkan tokoh yang sebenarnya, gambar memegang peranan yang sangat penting dalam proses pemahaman isi cerita.

2. Teks dalam pembuatan modul cerita bergambar, tentunya teks merupakan salah satu hal terpenting dalam penyampaian materi yang akan disampaikan kepada pembaca. Menurut (Sadiman,dkk 2019:93) mengemukakan pendapatnya bahwa terdapat 4 unsur kelayakan media teks (termasuk di dalamnya buku ajar bergambar), diantaranya: 
a) Komponen isi, mencakup kesesuaian dengan kurikulum pembelajaran, keakuratan dengan materi pendukung pembelajaran,

b) Komponen kebahasaan, yakni kesesuaian bahasa yag digunakan dengan tingkat perkembangan peserta didik, pemakaian bahasa yang komunikatif dan pemakaian bahasa memenuhi syarat keruntutan dan keterpaduan alur pikir,

c) Komponen penyajian, meliputi teknik penyajian pembelajaran dan kelengkapan informasi,

d) Komponen kegrafisan mencakup ukuran modul, desain kulit modul dan desain isi modul.

Modul cerita bergambar berbasis $e$ Learning yaitu sebuah modul yang dikemas untuk dapat digunakan dalam berbagai media elektronik, sebagai salah satu betntuk hasil dari kemajuan teknologi, sehingga bentuk akhir dari modul ini berupa elektronik modul atau elektronik buku yang dapat diakses melalui computer atau perangkat elektronik lainnya.

\section{METODE PENELITIAN}

Penelitian ini akan dilakukan di SD Negeri Serang 13, di kelas IV B dengan jumlah siswa 44 orang dan sampel penelitian 20 orang, penelitian ini bertujuan untuk mengetahui pengembangan modul cerita bergambar berbasis e-learning dalam proses pembelajaran, untuk mengetahui kelayakan pengembangan modul cerita bergambar berbasis e-learning dalam proses pembelajaran dan mengetahui hasil respon peserta didik terhadap pengebangan modul cerita bergambar berbasis e-learning. Penelitian yang akan dilaksanakan dengan kurun waktu tujuh bulan yaitu pada bulan November 2020 - Mei 2021.

Metode yang digunakan dalam penelitian ini yaitu metode penelitian dan pengembangan (Research and Development). Metode penelitian dan pengembangan yang digunakan peneliti mengacu pada desain penelitian metode pengembangan Borg \& Gall dalam (Sugiyono, 2018:298). Dari sepuluh langkah yang ada, penilitian ini dilaksanakn dengan menggunakan langkah penelitian hanya sampai pada tahap uji coba produk, yang artinya penelitian kali ini masih dalam uji coba produk dalam skala kecil, hal ini tentunya dengan pertimbangan beberapa hal, langkah tersebut adalah sebagai berikut:

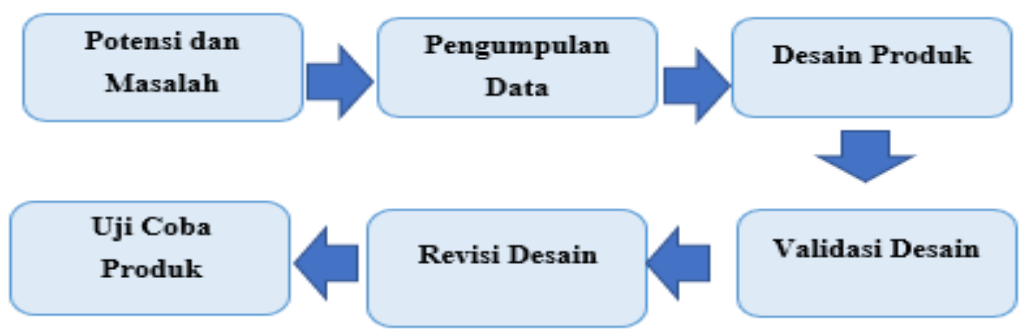

Gambar 1. Langkah-Langkah Metode Penelitian

\section{Potensi dan masalah}

Dalam penelitian yang akan dilakukan, peneliti melakukan analisi masalah dengan menggunakan analisis kebutuhan, analisis kurikulum dan analisis materi

a) Analisi kebutuhan, analisis kebutuhan dilakukan untuk mendapatkan berbagai informasi yang digunakan sebagai bahan awal untuk penyususnan Modul berbasis $e$ learning. Analisis kebutuhan ini dilakukan dengan Teknik wawancara kepada guru wali kelas IV di SDN Serang 13 yaitu ibu Hj. Hadizah S.Pd. 
ISSN : 2303-1514 | E-ISSN : 2598-5949

b) Analisis kurikulum, analisis kurikulum dilakukan untuk mengidentifikasi kedalaman dan keluasan kompetensi inti dan kompetensi dasar yang akan dijabarkan dalam indikator pembelajaran.

c) Analisis Materi, analisis materi dilakukan untuk menyususn modul agar sesuai dengan kompetensi yang telah ditentukan dan tujuan yang hendak dicapai. Materi disusun kembali secara sistematis dalam modul agar mudah dipahami oleh peserta didik sesuai dengan kompetenis inti dan kompetensi dasar yang terdapat dalam kurikulum pembelajarann.

\section{Penggumpulan data}

Mengumpulkan berbagai informasi atau data untuk dijadikan sebagai bahan yang digunakan dalam melakukan pengembangan produk, yang diharapkan dapat mengatasi masalah yang ada. Pengumpulan informasi ini peneliti melakukan dengan Teknik wawancara dan angket.

\section{Desain produk}

Setelah tahap analisis dn pengumpulan data dilaksanakan, maka selanjutnya adalah tahap desain produk yang diharapkan tahap desain ini terdiri dari tiga langkah, yaitu:

a. membuat Story Board modul.

b. mengumpulkan materi dan gambar.

c. menyusun modul yang sesuai dengan sistematika penyusunan.

\section{Validasi desain}

Tahap validasi desain ini dalah tahap penilaian produk yang telah dibuat untuk mengetahui apakah produk yang dirancang sudah memenuhi kriteria dan layak untuk uji coba atau masih harus diperbaiki. Validasi desain ini dilakukan dengan menghadirkan beberapa ahli yaitu: ahli materi, ahli media dan ahli bahasa yang sudah berpengalaman. Data validasi dari para ahli dianalisis secara deskriptif kuantitatif, dengan menggunakan Skala Likert dengan rentang skor 1 sampai 5 dengan keterangan sebagai berikut: 1) skor 1 mewakili pernyataan tidak layak, 2) skor 2 mewakili kurang layak, 3) skor 3 mewakili pernyataan cukup layak, 4) skor 4 mewakili layak, dan 5) skor 5 mewakili pernyataan sangat layak.

Tabel 1. Kisi-Kisi Instrumen Angket Penilaian Validasi Ahli Media

\begin{tabular}{cl}
\hline Aspek penilaia & \multicolumn{1}{c}{ Indikator } \\
\hline Desain Sampul Modul & Tata Letak Kulit Modul \\
& Huruf yang digunakan menarik dan \\
& mudah dibaca \\
& Ilustrasi sampul modul \\
& Konsistensi tata letak \\
& Unsur tata letak lengkap \\
Desain isi modul & Tipografi isi buku sederhana \\
& Ilustrasi isi \\
\hline
\end{tabular}

Sumber modifikasi (Purwono, 2008)

Tabel 2. Kisi-Kisi Instrumen Angket Penilaian Validasi Ahli Materi

\begin{tabular}{cc}
\hline Aspek penilaian & Indikator \\
\hline & Kesesuaian Materi Pembelajaran \\
Kelayakan isi & dengan KD \\
& Keakuratan Materi \\
Kelayakan penyajian & Pendukung Materi Pembelajaran \\
& Pendukung penyajian \\
& Kelengkapan Penyajian \\
\hline
\end{tabular}

(Purwono, 2008) 
ISSN : 2303-1514 | E-ISSN : 2598-5949

Tabel 3. Kisi-kisi instrumen angket penilaian validasi ahli bahasa

\begin{tabular}{ll}
\hline Aspek penilaian & \multicolumn{1}{c}{ Indikator } \\
\hline & Lugas \\
& Komunikatif \\
& Dialogis dan Interaktif \\
& Kesesuaian Dengan Tingkat Pekembangan \\
& Peserta Didik \\
& Kesesuaian Dengan Kaidah Bahasa \\
& Indonesia \\
& Penggunaan Istilah, Simbol dan Ikon \\
\hline &
\end{tabular}

Tabel 4. Kisi-kisi instrumen angket respon peserta didik

No. Aspek penilaian

Indikator

\begin{tabular}{rll}
\hline & & Kemenarikan gambar \\
1. & Tampilan media & Kejelasan teks \\
& & Kejelasan gambar \\
& Kesesuaian gambar dengan materi \\
2. & Penyajian materi & Penyajian materi \\
& Kejelasan kalimat \\
\hline
\end{tabular}

Penilaian angket validasi ahli dapat dihitung menggunakan rumus sebagai berikut

$$
\mathrm{NP}=\frac{\mathrm{R}}{\mathrm{SM}} \times 100 \%
$$

Keterangan: $\mathrm{NP}=$ Nilai presentse kelayakan yang diharapkan, $\mathrm{R}=$ Skor mentah yang diperoleh, $\mathrm{SM}=$ Skor maksimal tiap kriteria.

Angket respon siswa diberikan kepada siswa yang menjadi subyek uji coba sebanyak 20 siswa. Analisis angket respon siswa menggunakan Skala Guttman dengan keterangan sebagai berikut: skor 1 mewakili pernyataan "ya", dan skor 0 mewakili pernyataan "tidak". Penilaian angket respon peserta didik dapat dihitu ng menggunakan rumus sebagai berikut :

$$
\mathrm{P}=\frac{\mathrm{n}}{N} \times 100 \%
$$

Keterangan: $\mathrm{P} \quad$ : Presentase sikap peserta didik setiap indikator, $\mathrm{n}$ : Jumlah skor perolehan untuk setiap indikator, N: Jumlah skor total setiap indikator. Dari hasil validasi ahli dan angket repon peserta didik dikonversi kedalam kriteria penilan untuk dapat mengetahui tingkat kelayakan dan hasil respon yang didapatkan, kriteria kategori interpretasi tersebut dapat dilihat pada tabel berikut ini:

Tabel 1. Kriteria Kategori Interpretasi

\begin{tabular}{cc}
\hline Kriteria Validasi & Tingkat Validasi \\
\hline $81 \%-100 \%$ & Sangat layak \\
$61 \%-80 \%$ & Layak, \\
$41 \%-60 \%$ & Cukup layak \\
$21 \%-40 \%$ & Kurang layak \\
$0 \%-20 \%$ & Tidak layak \\
\hline
\end{tabular}

(Riduwan, 2019) 
Dari angket validasi ahli dan angket respon peserta didik dapat diketahui dan penarikan kesimulan bahwa bahan ajar yang dianggap layak untuk digunakan apabila memenuhi nilai interpretasi $\geq 61 \%$.

\section{Revisi desain}

Pada tahap revisi atau perbaikan desain, setelah peneliti melakukan validasi desain dengan beberapa ahli yang dibutuhkan serta telah mendapatkan hasil dari penilaian tersebut, apabila peneliti mendapatkan sebuah kekurangan atau kelemahan dari desain tersebut maka hal yang dilakukan adalah mengurangi kelemahan tersebut dengan melakukan perbaikan desain dengan masukanmasukan yang didpatkan.

\section{Uji coba produk}

Setelah produk telah melakukan perbaikan desain maka langkah berikutnya. Data dan sumber data yang digunakan peneliti saat ini dapat dilihat dari sumber datanya dapat menggunakan data primer dan data sekunder, seperti yang dikemukakan oleh (Sugiyono, 2018:137) mengatakan bahwa pengumpulan data dapat menggunakan data primer dan data sekunder. Sumber primer adalah sumber data yang langsung memberikan data kepada pengumpul data, dan sumber sekunder merupakan sumber yang diberikan secara tidak langsung berupa dokumen ataupun orang lain. Uji coba produk terbatas. Pengujian dilakukan dengan tujuan untuk mendapatkan informasi apakah produk yang dibuat tersebut lebih efektif dan efisien dibandingkan dengan produk terdahulu

\section{HASIL DAN PEMBAHASAN}

Pengembangan ini menggunakan model pengembangan yang telah dilakukan oleh Borg and Gall dengan 10 langkah. Namun, karena keterbatasan peneliti sehingga pengembangan ini hanya dilakukan hingga tahap 6 tahap pertama yaitu menemukan potensi dan masalah, pengumpulan data, desain produk, validasi produk, revisi produk dan uji coba produk.

Modul yang telah dibuat oleh peneliti terdiri dari cover depan, halaman judul, kata pengantar, daftar isi, deskripsi singkat, kompetensi dasar, peta konsep, petunjuk penggunaan modul, materi yang didalamnya terdapat lembar kerja peserta didik, kesimpulan, evaluasi, kunci jawaban, tindak lanjut dan refleksi, glosarium, daftar pustaka, profil penulis dan frofil pembimbing, dan halam terakhir cover belakang.

Selain komponen diatas modul cerita bergambar berbasis e-learning materi aktivitas ekonomi juga memiliki ikon thumbnails yaitu untuk melihat halaman secara keseluruhan, ikon untuk memperbesar dan memperkecil halaman, ikon auto flip yaitu agar modul secara langsung berpindah halam dari satu halam kehalaman lainnya tanpa menekan layar handphone, ikon untuk memutas dan mematikan backsound musik, ikon video galeri, ikon untuk mencetak modul dan terakhir informasi mengenai aplikasi FLIPHTML5.

Untuk menguji kelayakan modul cerita bergambar berbasis e-learning materi aktivitas ekonomi yang telah di buat maka dilakukan penilaian dari beberapa ahli yang berkompeten di bidangya, penilaian ini dilakukan kepada ahli media, ahli materi dan ahli bahasa. Hasil pengolahan data validasi dari setiap ahli mengenai modul cerita bergambar berbasis $e$ learning materi aktivitas ekonomi terangkum dalam tabel 2 berikut ini:

Tabel 2. Hasil Validasi Ahli

\begin{tabular}{cccc}
\hline No. & Tim Ahli & Presentase $(\%)$ & Kriteria \\
\hline 1. & Ahli media 1 dan 2 & $91 \%$ & Sangat layak \\
2. & Ahli bahasa 1 dan 2 & $83 \%$ & Sangat layak \\
3. & Ahli materi 1 dan 2 & $86 \%$ & Sangat layak
\end{tabular}



VOLUME 10 NOMOR 6 DESEMBER 2021

ISSN : 2303-1514 | E-ISSN : 2598-5949

DOI : http://dx.doi.org/10.33578/jpfkip.v10i6.8345

https://primary.ejournal.unri.ac.id/index.php/JPFKIP

Rata-rata keseluruhan

86\% Sangat Layak

Sumber: Data Diolah Peneliti (2021)

Hasil uji coba terbatas pada 20 orang peserta didik kelas IV-B SDN Serang 13

diperoleh data respon peserta didik sebagai berikut:

Tabel 3. Hasil Angket Respon Peserta Didik

\begin{tabular}{ccccc}
\hline \multirow{2}{*}{ No. } & Aspek penilaian & Presentase (\%) & \multirow{2}{*}{ Kriteria } \\
\hline 1. & Tampilan media & Pernyataan negatif & Pernyataan positif & Sangat Layak \\
2. & $\begin{array}{c}\text { Penyajian materi } \\
\text { penggunaan }\end{array}$ & $87 \%$ & $98 \%$ & \\
3. & & $94 \%$ & & \\
& Rata-rata keseluruhan & & Sumber: Data Diolah Peneliti (2021)
\end{tabular}

\section{Pembahasan}

Penelitian dengan tujuan untuk menghasilkan sebuah produk yang berupa modul cerita bergambar berbasis e-learning materi aktivitas ekonomi pada mata pelajaran ilmu pengetahuan sosial untuk siswa kelas IV sekolah dasar telah di SD Negeri Serang 13, di kelas IV B dengan jumlah siswa 44 orang dan sampel penelitian 20 orang, dengan melewati beberapa tahap penelitian seperti yang dilakukan oleh Borg and Gall dalam (Sugiyono, 2018:298) yang diawali dengan menemukan potensi dan masalah, pengumpulan data, desain produk, validasi produk, revisi produk dan uji coba produk.

Tahap pertama yaitu potesi dan masalah, penentuan potensi dan masalah adalah langkah awal untuk memulai penelitian, pada tahap ini peneliti melakukan wawancara mengenai analisis kebutuuhan, analisis kurikulum dan analisis materi yang akan digunakan dalam pengembangan modul cerita bergambar berbasis e-learning materi aktivitas ekonomi untuk kelas IV sekolah dasar,

Tahap kedua yaitu tahap pengumpulan data ini dilakukan dengan menggunakan Teknik wawancara dan angket, kedua teknik ini juga telah dilakukan pada tahap awal yaitu tahap analisis potensi dan masalah. Selain menggunakan teknik wawancara dan angket, untuk lebih memperdalam dan keluasan data yang digunakan dalam penelitian dan pengembangan modul cerita bergambar berbasis e-learning peneliti juga menggunakan beberapa referensi materi yang akan digunakan, referensi ini berupa buku guru, buku siswa Tema 7 (Indahnya Keberagaman di Negeriku), buku paket KTSP 2006 mata pelajaran IPS Kelas IV SD/MI. Selain pengumpulan referensi untuk materi, peneliti juga mengumpulkan bahan-bahan pendukung lainnya

Tahap ketiga yaitu desain produk, pembuatan produk dimulai dengan perancangan cerita bergambar berbasis $e$ learning materi aktivitas ekonomi ini dilakukan untuk lebih memperjelas konsep pembuatan modul. Setelah membuat storyboard modul, tahap selanjutnya yaitu penyusunan dan pembuatan modul cerita bergambar berbasis e-learning dengan menggunakan beberapa bantuan aplikasi yaitu power point, background eraser. Aplikasi power point digunakan untuk membuat modul mulai dari background, isi materi, gaambar atau ilustrasi yang digunakan, disatukan dalam aplikasi power point,aplikasi background eraser digunakan untuk menghilangkan background gambar yang digunakan sehingga sesuai dengan yang diinginkan penulis. Setelah modul cerita bergambar berbasis $e$ learning sudah dibuat maka langkah selanjutnya yaitu mengubah bentuk modul dari bentuk awal PPT diubah menjadi bentuk PDF, kemudian modul ini dipublikasi secara online dengan menggunakan aplikasi FLIPHTML5 
sehingga bentuk akhir setelah melakukan publikasi modul ini dapat berupa html atau link yang mampu diberikan dan disebarluaskan kepada khalayak umum atau pembaca terutama peserta didik.

Setelah membuat dan menyususn modul cerita bergambar berbasis e-learning. Tahap selanjutnya adalah melakukan validasi dengan beberapa ahli diantanya yaitu: ahli desain, ahli bahasa, dan ahli materi. Tahap validasi ini dilakukan dengan tujuan untuk memperoleh masukan, pendapat, saran dan evaluasi terhadap modul cerita bergambar berbasis e-learning yang telah dibuat, sehingga pembuatan modul cerita bergambar berbasis $e$ learning ini dapat dibuat dengan lebih baik. Validasi ini dilakukan dengan ahli media, ahli bahasa dan ahli materi. Penilaian validasi ahli media yang dilakukan kepada dua ahli jumlah skor penilaian dari ahli media 1 sebesar 117 dari jumlah maksimal 150 dengan persentase 93\%. Sedangkan skor penilaian validasi ahli media 2 didapatkan 117 dari nilai maksimal 150 dengan persentase $93 \%$ dan nilai rata-rata dari kedua ahli media sebesar $91 \%$. Berdasarkan kategori interpretasi menurut (Riduwan, 2019:89) nilai tersebut termasuk kedalam kriteria "sangat layak".

Penilaian validasi ahli bahasa didapatkan dengan jumlah skor penilaian dari ahli bahasa 1 sebesar 52 dari jumlah maksimal 60 dengan persentase 83\%. Sedangkan skor penilaian validasi ahli bahasa 2 didapatkan 48 dari nilai maksimal 60 dengan persentase $80 \%$ dan nilai rata-rata dari kedua ahli bahasa sebesar $83 \%$. Dengan demikian, berdasarkan kategori interpretasi menurut (Riduwan, 2019:89) nilai tersebut termasuk kedalam kriteria "sangat layak". penilaian validasi ahli materi diatas, didapatkan bahwa jumlah skor penilaian dari ahli materi 1 sebesar 80 dari jumlah maksimal 100 dengan persentase $80 \%$. Sedangkan skor penilaian validasi ahli materi 2 didapatkan 92 dari nilai maksimal 100 dengan persentase $92 \%$ dan nilai rata-rata dari kedua ahli materi sebesar $86 \%$ sehingga termasuk kedalam kategori sangat layak.
Setelah dilakukannya uji validasi terhadap modul cerita bergambar berbasis $e$ learning, tahap berikutnya yaitu revisi produk. Pada tahap ini peneliti melakukan revisi dan perbaikan atas arahan dari setiap validator ahli pada saat melakukan validasi, tahap ini bertujuan untuk melengkapi kekurangankekurangan pada modul cerita bergambar berbasis e-learning sehingga produk yang dihasilkan dapat sempurna.

Tahap terakhir adalah uji coba produk secara terbatas yang dilakukan di SDN Serang 13, modul ini diuji cobakan kepada peserta didik kelas IV B sebanyak 20 orang peserta didik. Pada uji coba produk ini, peneliti dan guru kelas IV B melaksanakan pembelajaran secara daring melalui aplikasi WhathsApp pada materi Aktivitas ekonomi dengan menggunakan modul cerita bergambar berbasis e-learning dengan jumlah sampel 20 orang peserta didik. Berdasarkan hasil angket respon yang diberikan kepada peserta didik hasil skor penilaian dari pernyataan negatif 87 dari jumlah maksimal 100 dengan persentase $87 \%$. Sedangkan skor penilaian dari pernyataan positif didapatkan 197 dari nilai maksimal 200 dengan persentase $98 \%$ dan nilai rata-rata dari pernyataan positif dan negatif sebesar $94 \%$. Dengan demikian, berdasarkan kategori interpretasi menurut (Riduwan, 2019:89) nilai tersebut termasuk kedalam kriteria "sangat baik".

\section{SIMPULAN DAN REKOMENDASI}

Prosedur penelitian dan pengembangan terhadap modul cerita bergambar berbasis e-learning materi aktivitas ekonomi yang dilaksanakan melalui enam tahap yaitu, yang diawali dengan menemukan potensi dan masalah,pengumpulan data, desain produk, validasi produk terhadap validatorahli (ahli media, bahasa dan materi), revisi produk dan uji coba produk (terbatas).

Kelayakan modul cerita bergambar berbasis e-learning materi aktivitas ekonomi setelah melalui validasi ahli didapatkan hasil sebesar $86 \%$ hal ini menunjukan bahwa 
kelayakan modul cerita bergambar berbasis $e$ learning materi aktivitas ekonomi termasuk kedalam kategori "Sangat Layak".

Respon peserta didik berdasarkan uji coba produk secara terbatas pada kelas IV B SDN Serang 13 mendapatkan nilai persentase angket respon peserta didik sebesar 94\% yang masuk kedalam kategori "Sangat Baik".

\section{Rekomendasi}

Berdasarkan pada pengalaman peneliti dalam melakukan penelitian menyarankan bagi peneliti selanjutnya yang akan mengembangkan modul cerita bergambar berbasis e-learning, diharapkan dapat mengembangkan berbasis teknologi lain yang dibutuhkan oleh pengguna serta dengan menggunakan pokok bahasan yag berbeda agar menambah ketersediaan bahan ajar bagi pengguna.

\section{DAFTAR PUSTAKA}

Afnida, M. (2016). Penggunaan Buku Cerita Bergambar Dalam Pengembangan Bahasa Anak Pada Teka A Di Banda Aceh. Jurnal Ilmiah Mahasiswa Pendidikan Anak Usia Dini, 1(3), 53.

Aprilia, N. (2018). Pengembangan Buku Cerita Bergambar Berbasis Pendidikan Lingkungan Hidup Untuk Pembelajaran Membaca Di Kelas II $S D$. universitas Jambi.

Ariesta, F. W. dan E. N. K. (2018). Pengembangan Media Komik Berbasis
Masalah untuk Peningkatan Hasil Belajar IPS Siswa Sekolah Dasar. Pendas: Jurnal Ilmiah Pendidikan Dasar, 3(1), 26.

Darmawan. (2016). Pengembangan ELearning Teori dan Desain. PT Remaja Rosdakarya.

Harista, A. Q. Q. (2020). Efektivitas Pengembangan Modul Pembelajaran Berbasis E-Learning Pada Mata Kuliah Perawatan Kulit Wajah. Jurnal Imiah Pendidikan Dan Pembelajaran., 4(1), 154.

Jamaludin, U. (2018). Pembelajaran Pendidikan IPS Teori Konsep dan Aplikasi Bagi Guru dan Mahasiswa. Penerbit Nurani.

Prastowo, A. (2012). Panduan Kreatif Membuat Bahan Ajar Kreatif. DIVA Press.

Purwono, U. (2008). Standar Penilaian Buku Pelajaran. Universitas Terbuka.

Riduwan. (2019). Belajar Mudah Penelitian untuk Guru-Karyawan dan Peneliti Pemula. ALFABETA.

Sadiman. (2019). Media Pendidikan (Pengertian, Pengembangan dan Pemanfaatannya). Grafindo Persada.

Sugiyono. (2018). Metode Penelitian Kuantitatif, Kualitatif dan $R \& D$. Alfabeta.

Sutoyo. (2009). IPS 4 untuk SD/MI Kelas 4. usat Perbukuan Departemen Pendidikan Nasional. 